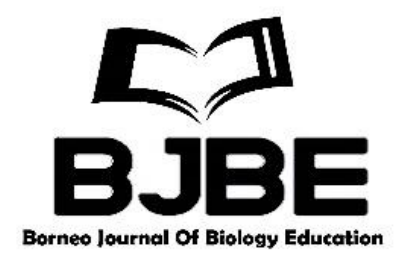

Vol. 1 No. 2, 2019; pp. 99-106

P-ISSN: 2715-6826 (print); E-ISSN: 2714-6073 (online)

Received: 02/07/2019

Revised: 07/08/2019

Accepted: 15/10/2019

\title{
KAJIAN BIOLOGI DAN BUDAYA MASYARAKAT SUKU DAYAK DAN TIDUNG DI DAERAH TARAKAN DALAM PEMANFAATAN BUAH-BUAHAN
}

\section{Study of Biology and Culture in Dayak and Tidung Tribes in Tarakan on The Use of Different Fruits}

\author{
Indriani $^{\mathrm{a}^{*}}$, Bella Anggraini ${ }^{\mathrm{a}}$, Putri Halimah ${ }^{\mathrm{a}}$
}

\begin{abstract}
aProgram Studi Pendidikan Biologi, Universitas Borneo Tarakan, Kalimantan Utara
*corresponding author: Jl. Amal Lama, Tarakan Timur, Tarakan, Kalimantan Utara, 77123, Indonesia. E-mail:

indrianiibrahim03@gmail.com
\end{abstract}

\begin{abstract}
Abstrak
Tujuan penelitian ini adalah untuk mengidentifikasi jenis buah-buahan yang digunakan dalam kehidupan sehari-hari Suku Tidung dan Dayak di Tarakan. Pengumpulan data menggunakan teknik snowball sampling, dan total orang yang diwawancarai sebanyak 6 orang. Hasil dari penelitian didapatkan terdapat 25 jenis buah-buahan yang digunakan olah Suku Tidung dan dayak, dan Genus Artocarpus merupakan jenis yang terbanyak dibandingkan yang lainnya.
\end{abstract}

Kata kunci

Buah-Buahan, Dayak, Tidung Tarakan

\section{Abstract}

The aim of this research is to indentify the species of fruits that is used in daily life of Tidung and Dayak Tribes in Tarakan. Data collection used snowball sampling, and the total number of interviewees in this research was 6 people. Then, the result showed that there are 25 species of fruits was used by Tidung and Dayak Tribes. Genus Artocarpus was the largest number of usage among others. .

Keywords

Fruits, Dayak, Tidung, Tarakan

\section{Pendahuluan}

Kalimantan Utara merupakan salah satu provinsi di Indonesia dengan masyarakat yang sangat heterogen. Setidanyaknya terdapat 5 suku asli di daerah ini, yaitu: Suku Dayak, Suku Banjar, Suku Tidung, Suku Bulungan dan Suku Kutai. Selain itu, terdapat kelompok besar suku pendatang 


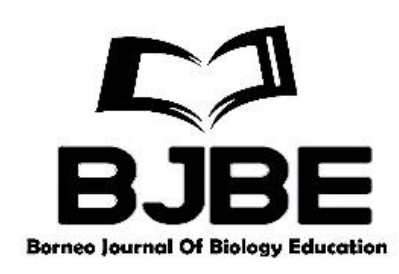

yang terdiri dari Suku Jawa, Suku Bugism dan Suku Toraja (Pemprov Kaltara, 2019). Suku Dayak dan Tidung merupakan suku asli yang mendiami Kalimantan Utara, khususnya di daerah Tarakan. Setidaknya terdapat 6 rumpun Suku Dayak yang mendiami Kalimantan Utara, sementara untuk Suku Tidung semua rumpunnya mendiami Kalimantan Utara dan sebagian di daerah Malaysia (Fakhrozi, 2009).

Suku Dayak dan Tidung dalam beberapa versi memiliki beberapa kedekatan. Hamzah (1999) menyatakan setidaknya ada 3 versi terkait asal usul suku Tidung. Dia berpendapat versi pertama menyatakan bahwa Suku Tidung berasal dari Asia, yang kemudian orang-orang Asia ini mendarat di daerah pantai Timur Kalimantan Utara serta menyebar ke pesisir pantai dan tepi sungai. Namun, penyebaran ini medapatkan perlawanan dari penduduk lokal sehingga mereka berpindah ke daerah hutan dan hulu sungai yang dikenal dengan Dayak Kayan. Seiring berjalannya waktu, mereka mulai menempati daerah Kalimantan Utara dan beberapa daerah di Malaysia (Labuk, Tawau, Kelumpang, Selungun dan daerah lain yang berbatasan dengan Kalimantan Utara). Beberapa daerah ini akhirnya disebut dengan Tana Tidung. Versi kedua merupakan versi Hindia-Belanda menyatakan bahwa suku Tidung berasal dari Dayak Kayan, dan menyatakan Suku Tidung asli hanya yang bermukim di Sesayap dan Malinau. Namun, versi ini dianggap berbau kepentingan politik, dan menganggap suku Tidung lainnya bukan merupakan suku asli. Versi terakhir merupakan versi dari pemerintah Indonesia yang menyatakan Suku Tidung berasal dari Dayak Pantai yang berasal dari pegunungan di Menjelutung.

Kedekatan kedua suku tersebut dari segi historis juga menggambarkan kedekatan mereka dalam pemanfaatan sumber daya alam, khususnya buah-buahan. Pemanfaatan buahbuah dimanfaatkan sebagai bahan pangan, maupun sebagai pengobatan. Beberapa inventarisasi telah dilakukan terkait penggunaan buah-buahan dalam kehidupan Suku Dayak dan Tidung di Kalimantan Utara. Penelitian telah dilakukan di Malinau (Setiawan et al., 2019; Suparman et al., 2017), Nunukan, dan Bulungan (Listiani \& Abrori, 2019). Penelitian ini bertujuan untuk menginventarisasi jenis buah-buahan yang dimanfaatkan oleh suku Tidung dan Dayak di Daerah Tarakan.

\section{Waktu, Tempat, dan Informan}

\section{Material dan Metode}

Metode yang digunakan dalam penelitian ini adalah metode survey. Penentuan informan memggunakan metode snowball sampling. Penentuan informan berdasarkan satu informan kunci, kemudian informan kunci memberikan rekomendasi untuk informan selanjutnya. Informan yang diwawancarai ada 36 informan yang terdiri 18 orang informan dari suku Dayak Kenyah dan 18 orang informan dari suku Tidung. Penelitian ini telah dilaksanakan pada tanggal 12 April - 25 Mei 2018, dan bertempat di Selumit Pantai, Tarakan (N 3¹7'44.4084" E 177³5’0.456”), dan Karang Anyar, Tarakan (N 3¹9’25.608” E 177³4’43.8708”). 

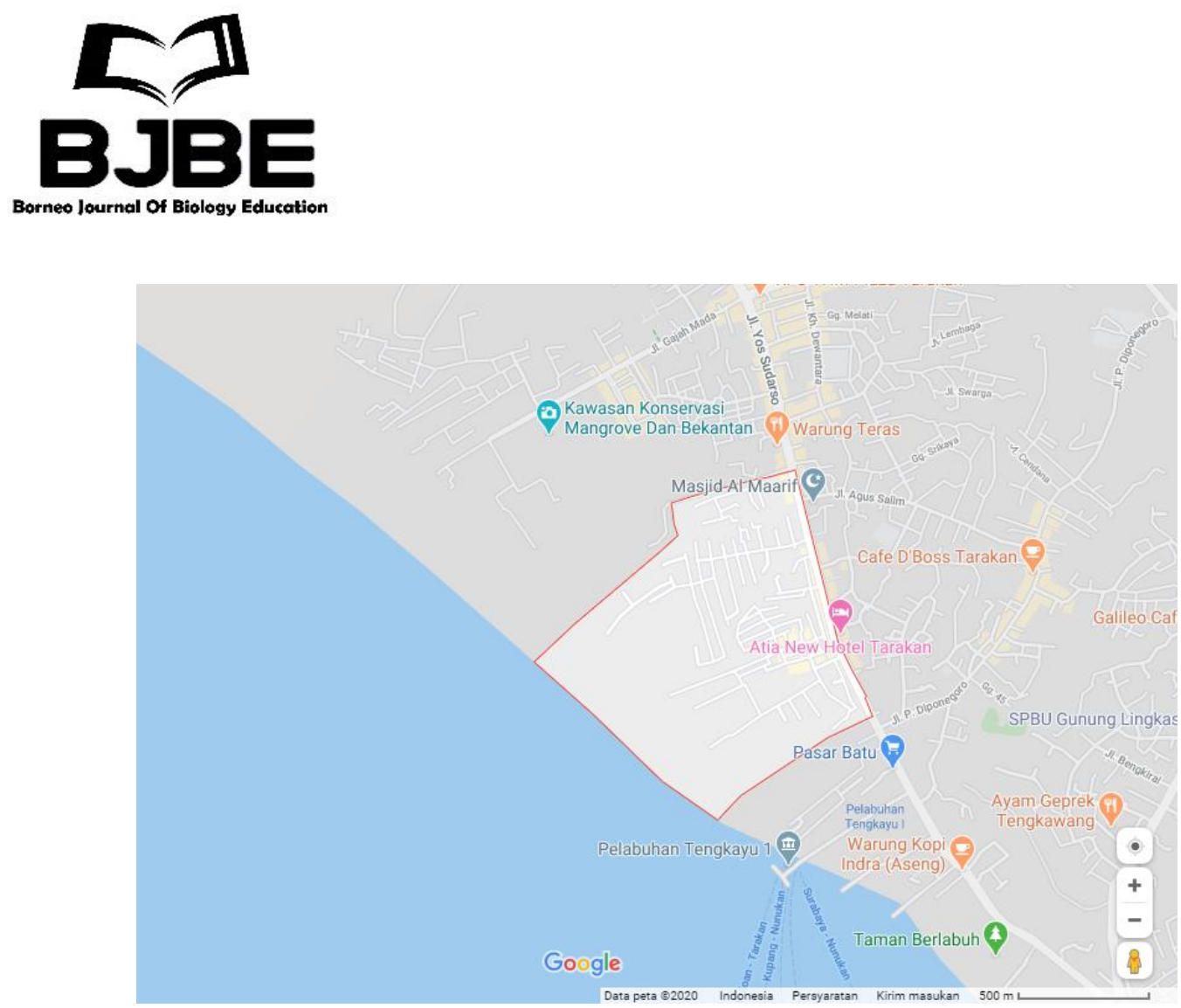

Gambar 1. Selumit Pantai, Tarakan (sumber: google map)

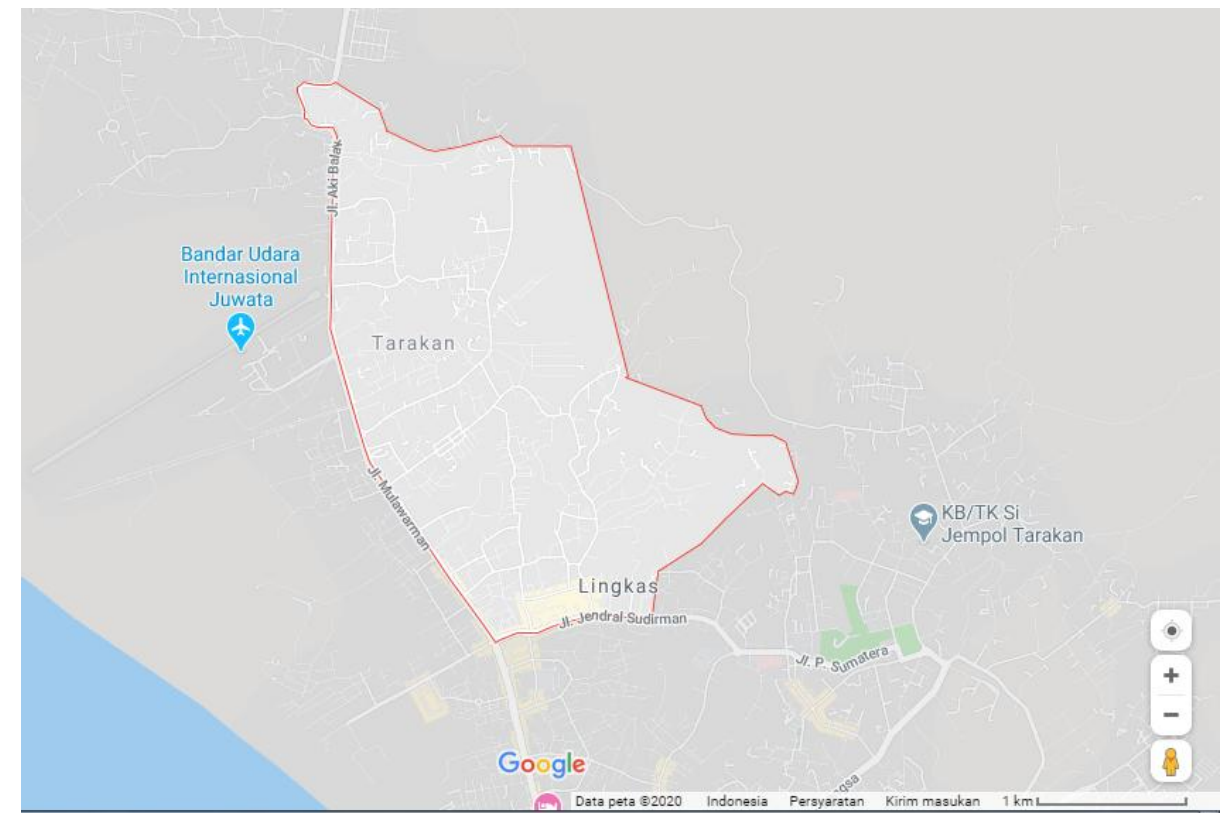

Gambar 2. Karang Anyar, Tarakan (sumber: google map)

\section{Pengumpulan Data Jenis Buah-Buahan}

Survei menggunakan metode participatory rural appraisal (PRA) yang mengacu kepada Kim \& Song (2011) yang dimana informan yang mengumpulkan data juga bertindak 


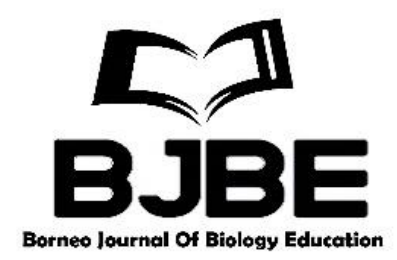

sebagai penyidik. Pengumpulan data melibatkan beberapa kegiatan seperti: wawancara, pertemuan informal, diskusi terbuka, diskusi kelompok dan pengisian kuesioner semiterstruktur. Berdasarkan hasil dari survey maka didata beberapa jenis buah-buahan dan penggunaannya dalam kehidupan masyarakat.

\section{Pengukuran Fidelity Level}

Selain mengamati jenis buah-buahan yang dimanfaatkan oleh masyarakat, dilakukan juga perhitungan tingkat kesukaan (fidelity level) masyarakat terhadap buah tersebut yang mengacu kepada Friedmen et al., (1986) dengan menggunakan Formula 1.

$$
\text { FL }(\%)=\operatorname{Np} \times \frac{100}{N}(\text { Formula } 1)
$$

Keterangan

$\mathrm{Np} \quad=$ jumlah informan yang mengklaim penggunaan spesies untuk pangan/ kegunaan pangan tertentu yang dianggap penting

$\mathrm{N} \quad=$ jumlah total informan yang memberikan informasi spesies

\section{Detail Demografi dari Informan}

\section{Hasil dan Diskusi}

Informan dari kedua suku memiliki latar belakang yang berbeda. Latar belakang yang dimaksud adalah gender, pendidikan terakhir, dan umur. Detail latar belakang informan dari kedua suku disajikan pada Tabel 1.

Tabel 1. Demografi Informan

\begin{tabular}{lcc}
\hline \multirow{2}{*}{ Aspek } & \multicolumn{2}{c}{ Jumlah (orang) } \\
\cline { 2 - 3 } & Dayak Kenyah & Tidung \\
\hline Gender & 10 & 14 \\
• Laki-Laki & 8 & 4 \\
Pendidikan Terakhir & & \\
- SD & 10 & 9 \\
- SMP & 4 & 2 \\
- SMA & 3 & 5 \\
Smur & 1 & 2 \\
- $20-29$ & & 2 \\
- 30-39 & - & 2 \\
- $40-49$ & 1 & 6 \\
- $50-59$ & 10 & 5 \\
\hline
\end{tabular}




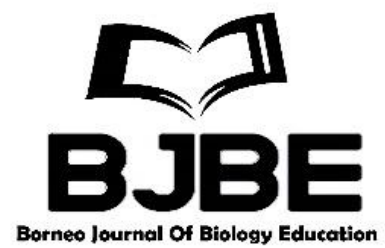

\section{Data Buah-Buahan dan Nilai Fidelity Level}

Berdasarkan hasil pengumpulan data pada 36 orang Suku Dayak Kenyah dan Tidung didapatkan setidaknya 25 jenis tumbuhan yang buahnya dimanfaatkan oleh masyarakat sekitar sebagai bahan pangan atau sebagai obat yang. Tumbuhan tersebut dikelompokkan dalam 15 suku. Daftar jenis buah-buahan yang dimanfaatkan disajikan pada Tabel 2.

Tabel 2. Jenis Buah-Buahan yang dimanfaat Masyarakat

\begin{tabular}{|c|c|c|c|c|c|}
\hline No & Suku & $\begin{array}{c}\text { Spesies } \\
\end{array}$ & Nama Lokal & Manfaat & Nilai FL \\
\hline \multirow[t]{5}{*}{1.} & Moraceae & Artocarpus camansi Blanco & Keminci & Pangan & 83.33 \\
\hline & & Artocarpus altilis (Parkinson) & Sukun & Pangan & 83.33 \\
\hline & & $\begin{array}{l}\text { Fosberg } \\
\text { Artocarpus heterophyllus Lam. }\end{array}$ & Bangka & $\begin{array}{l}\text { Pangan, pengering } \\
\text { pusat bayi saat ari ari } \\
\text { lepas }\end{array}$ & 88.89 \\
\hline & & Artocarpus integer Spreng. & Tudak & Pangan & 97.22 \\
\hline & & $\begin{array}{l}\text { Artocarpus odoratissimus } \\
\text { Blanco }\end{array}$ & Madang & Pangan & 86.11 \\
\hline 2. & Gnetaceae & Gnetum gnemon L. & Melinjo & $\begin{array}{l}\text { Mempercepat } \\
\text { persalinan }\end{array}$ & 83.33 \\
\hline 3. & Rubiaceae & Morinda citrifolia $\mathrm{L}$. & Mengkudu & Mengobati komplikasi & 41.67 \\
\hline 4. & Bromeliaceae & Ananas comosus (L.) Merr. & Berunai & $\begin{array}{l}\text { Mengobati amandel, } \\
\text { pangan }\end{array}$ & 25.00 \\
\hline 5. & Cucurbitaceae & Momordica charantia L. & Pare & $\begin{array}{l}\text { Menghilangkan kudis, } \\
\text { pangan }\end{array}$ & 50.00 \\
\hline 6. & Annonaceae & Annona muricata $\mathrm{L}$. & $\begin{array}{l}\text { Bangka } \\
\text { belanda }\end{array}$ & Obat tekanan, pangan & 52.78 \\
\hline \multirow[t]{2}{*}{7.} & Arecaceae & Areca catechu $\mathrm{L}$. & Pinang & Obat sakit gigi & 55.56 \\
\hline & & Cocos nucifera L. & $\begin{array}{l}\text { Nyirui / } \\
\text { Piasau }\end{array}$ & $\begin{array}{l}\text { Obat komplikasi, } \\
\text { pangan }\end{array}$ & 88.89 \\
\hline \multirow[t]{2}{*}{8.} & Myrtaceae & Psidium guajava L. & Jambu Biji & $\begin{array}{l}\text { Mengobati diare, } \\
\text { pangan }\end{array}$ & 61.11 \\
\hline & & $\begin{array}{l}\text { Syzygium aquenum (Burm.f.) } \\
\text { Alston }\end{array}$ & Janggus & Pangan & 69.44 \\
\hline \multirow[t]{4}{*}{9.} & Solanaceae & Pshysalis peruviana $\mathrm{L}$ & Ciplukan & Mengobati sariawan & 63.89 \\
\hline & & Solanum torvum $\mathrm{Sw}$. & Ucung Ace & Pangan & 72.22 \\
\hline & & Capsicum annum $\mathrm{L}$. & Bawu / Sabi & Pangan & 91.67 \\
\hline & & Solanum lycopersicum L. & Tomat & Pangan & 94.44 \\
\hline 10 & Pandanaceae & Pandanus amaryllifolius Roxb. & Pandan & $\begin{array}{l}\text { Mengobati darah } \\
\text { tinggi, pangan }\end{array}$ & 47.22 \\
\hline 11 & Rutaceae & $\begin{array}{l}\text { Citrus aurantifolia (Christm.) } \\
\text { Swingle }\end{array}$ & Limau & $\begin{array}{l}\text { Radang tenggorokan, } \\
\text { pangan }\end{array}$ & 55.56 \\
\hline \multirow[t]{2}{*}{12} & Fabaceae & $\begin{array}{l}\text { Leucaena leucocephala (Lam.) } \\
\text { de Wit }\end{array}$ & Petai Cina & Pangan & 58.33 \\
\hline & & Vigna cylindrica (L.) Skeels & Engkayo & Pangan & 61.11 \\
\hline 13 & Oxalidaceae & Averrhoa bilimbi $\mathrm{L}$. & $\begin{array}{l}\text { Belimbing } \\
\text { Tunjuk }\end{array}$ & Pangan & 61.11 \\
\hline 14 & Anacardiaceae & Mangifera indica L. & Pempalom & Pangan & 69.44 \\
\hline 15 & Sapindaceae & Nephelium lappaceum L. & Kebulu & Pangan & 75.00 \\
\hline
\end{tabular}




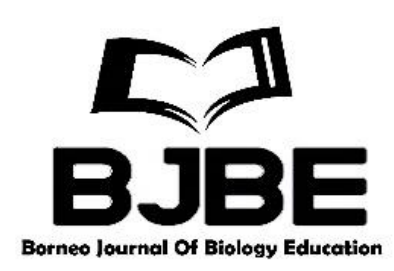

Berdasarkan hasil dari pengumpulan data, penggunaan buah-buahan banyak dimanfaatkan sebagai bahan pangan. Buah banyak dimanfaatkan menjadi bahan pangan karena memiliki kandungan air dan glukosa yang tinggi. Pardede (2013) menyatakan bahwa kandungan air dalam buah bisa mencapai $80-90 \%$, selain itu buah memiliki karbohidrat dalam bentuk fruktosa dan glukosa, sehingga dapat dijadikan bahan pangan untuk sumber energi.

Selain sebagai bahan pangan, buah juga banyak dimanfaatkan sebagai bahan untuk pengobatan. karena banyak mengandung gizi yang baik. Antarlina (2009) menyatakan bahwa buah merupakan sumber utama vitamin, khususnya vitamin A dan vitamin C. Selain itu buah juga kaya akan mineral, dan mengandung lemak dan protein. Beberapa komposisi nilai gizi dalam buah dan kekhasan senyawa pada setiap buah memberikan potensi sebagai obat.

Berdasarkan hasil pengumpulan data, genus terbanyak yang digunakan adalah suku Moraceae sebanyak 5 spesies. Pemanfaatan suku Moraceae dalam kehidupan masyarakat di Indonesia sangat banyak digunakan sebagai bahan pangan, baik dimakan tanpa diolah, ataupun diolah terlebih dahulu. Susiarti \& Rahayu (2003) menyatakan suku ini banyak dimanfaatkan sebagai lauk, gorengan, dan campuran beberapa minuman, bahkan buah yang belum masak seperti Artocarpus heterophyllus juga dimanfaatkan menjadi sup atau makanan berkuah.

Suku selanjutnya yang paling banyak dimanfaatkan adalah suku Solanaceae. Suku ini banyak dimanfaatkan oleh masyarakat sebagai bahan pangan utama, atau sebagai rempah. Febrianti \& Krisnawati (2018) menyatakan bahwa suku ini khususnya pada genus Solanum dan Capsicum banyak dimanfaatkan sebagai rempah, khususnya dalam pembuatan sambal yang banyak dikonsumsi oleh masyarakat Indonesia.

Berdasarkan hasil perhitungan fidelity level didapatkan nilai tertinggi pada Artocarpus integer. Jansen (1997) menyatakan bahwa secara alami, Artocarpus integer mampu tumbuh hingga ketinggian $1000 \mathrm{mdpl}$, dan menyukai daerah dengan permukaan air tanah yang dangkal. Dia juga berpendapat pemanfaatan tumbuhan ini banyak dimanfaatkan melalui konsumsi secara langsung, atau dicampur dengan tepung dan digoreng. Bahkan, pemanfaatan lainnya yaitu kulit dan biji tumbuhan ini dimanfaatkan untuk dikonsumsi melalui beberapa proses pengolahan (Nauw et al., 2016).

\section{Kesimpulan}

Berdasarkan hasil penelitian maka dapat disimpulkan hasil pengumpulan data terkait jenis buah-buahan yang dimanfaatan oleh suku Dayak dan Tidung di daerah Tarakan didapatkan data bahwa tumbuhan terbanyak yang dimanfaatkan oleh masyarakat adalah suku Moraceae sebanyak 5 spesies, dan selanjutnya adalah suku Solanaceae sebanyak 4 spesies. Berdasarkan nilai fidelity level didapatkan nilai bahwa spesies Artocarpus integer merupakan spesies yang pemanfaatannya sangat bervariatif oleh masyarakat 


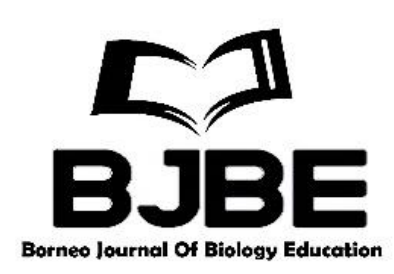

Sebagai saran untuk penelitian selanjutnya, data penelitian ini dapat dikembangkan sebagai bahan ajar pada materi terkait etnobiologi. Data juga dapat dikumpulkan sebagai inventaris jenis-jenis tumbuhan yang dimanfaatkan di daerah Tarakan.

\section{Referensi}

Antarlina, S. S. (2016). Identifikasi sifat fisik dan kimia buah-buahan lokal Kalimantan. Buletin Plasma Nutfah, 15(2), 80-90.

Fakhrozi, I, 2009, Etnobotani Masyarakat Suku Melayu Tradisional Di Sekitar Taman Nasional Bukit Tigapuluh, Fakultas Kehutanan Institut Pertanian Bogor

Febrianti, Y., \& Krisnawati, Y. (2018). Studi Ekologi dan Pemanfaatan Tumbuhan Famili Solanaceae di Kecamatan Tugumulyo. Biota, 11(1), 57-66.

Friedman, J., Yaniv, Z., Dafni, A., \& Palewitch, D. (1986). A preliminary classification of the healing potential of medicinal plants, based on a rational analysis of an ethnopharmacological field survey among Bedouins in the Negev Desert, Israel. Journal of ethnopharmacology, 16(2-3), 275-287.

Irawan, YR, Fitmawati \& Herman, 2013, Pengetahuan Tanaman Obat Dukun Sakai Desa Sebangar Duri Tiga Belas \& Desa Kesumbo Ampai Duri Kabupaten Bengkalis, Jurnal Biosaintifika, 5 (1): 191-208

Jansen, P. C. M. (1997). Artocarpus JR and G. Foster, dalam Verheij, EWM Dan RE Colonel. Buah-buahan yang dapat dimakan. Sumber Daya Nabati Asia Tenggara (PROSEA), 2, 87-91.

Listiani, L., \& Abrori, F. M. (2019). Ethnobotanical Study on Tidung Tribe in Using Plants for Medicine, Spice, and Ceremony. IPTEK The Journal for Technology and Science, 29(1), 18-24.

Kim, H., \& Song, M. J. (2011). Analysis and recordings of orally transmitted knowledge about medicinal plants in the southern mountainous region of Korea. Journal of Ethnopharmacology, 134(3), 676-696.

Nauw, A. J. R., Fatem, S. M., Husodo, S. B., \& Sagrim, M. (2016). Pemanfaatan tumbuhan cempedak (Artocarpus champeden) oleh masyarakat Kampung Sabun Distrik Aitinyo Tengah Kabupaten Maybrat, Papua Barat. Jurnal Ilmu Kehutanan, 10(1), 46-56.

Pardede, E. (2013). Tinjauan komposisi kimia buah dan sayur: Peranan sebagai nutrisi dan kaitannya dengan teknologi pengawetan dan pengolahan. J. VISI, 21(3), 1-16. 


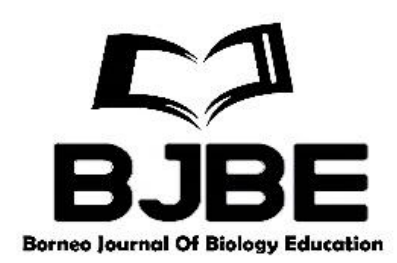

Setiawan, A., Listiani, L., \& Abrori, F. M. (2019). Kajian Etnobotani Tumbuhan Obat Suku Dayak Lundayeh di Desa Kaliamok Kecamatan Malinau Utara Kabupaten Malinau Sebagai Booklet untuk Masyarakat. Borneo Journal of Biology Education, 1(1), 5167.

Sjahid, LR, Wardeneaar,E, \& Muflihati, 2014. Etnobotani Tumbuhan Obat Disusun Serambai Kecamatan Kembayan Kabupaten Sanggau Kalimantan Barat. ,Jurnal Hutan Lestari 2 (3): 379-387.

Suparman, A., \& Rupa, D. (2018). Identification of Secretory Structure and Histochemical of Family Araceae as Medicinal Plants by Dayak Kenyah Tribe. Applied Science and Technology, 1(2), 26-30.

Susiarti, S., \& Rahayu, R. D. (2003). Pemanfaatan Tumbuhan Dalam Kehidupan Masyarakat Suku Muyu didesa Soa Dan Sekitarnya, Merauke, Papua. Berita Biologi, 6(5), 705711. 